\title{
GPS evidence for northward motion of the Sinai Block: Implications for E. Mediterranean tectonics
}

\author{
Salah Mahmoud ${ }^{\mathrm{a}, *}$, Robert Reilinger ${ }^{\mathrm{b}, 2}$, Simon McClusky ${ }^{\mathrm{b}, 2}$, \\ Philippe Vernant ${ }^{\mathrm{b}, 2}$, Ali Tealeb ${ }^{\mathrm{a}, 1}$

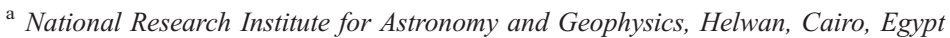 \\ b Department of Earth, Atmospheric, and Planetary Sciences, MIT, Cambridge, MA, USA
}

Received 18 November 2004; received in revised form 8 June 2005; accepted 10 June 2005

Available online 22 August 2005

Editor: S. King

\begin{abstract}
GPS survey sites in the Sinai Peninsula show northerly motion relative to Africa (Nubia) at $1.4 \pm 0.8 \mathrm{~mm} / \mathrm{yr}$ north and $0.4 \pm 0.8 \mathrm{~mm} / \mathrm{yr}$ west. Continuous IGS GPS sites in Israel, west of the Dead Sea fault show a similar northerly sense of motion relative to Nubia $(2.4 \pm 0.6 \mathrm{~mm} / \mathrm{yr}$ north and $0.04 \pm 0.7 \mathrm{~mm} / \mathrm{yr}$ east), suggesting that the entire Sinai Block south of Lebanon is characterized by northward translation relative to the Nubian plate. We develop an elastic block model constrained by the GPS results that is consistent with the regional tectonics and allows us to estimate slip rates for Sinai bounding faults, including the Gulf of Aqaba-southern Dead Sea fault system $(\sim 4.4 \pm 0.3 \mathrm{~mm} / \mathrm{yr}$, left lateral), the Gulf of Suez $(1.9 \pm 0.3 \mathrm{~mm} / \mathrm{yr}$ left lateral, and $1.5 \pm 0.4 \mathrm{~mm} / \mathrm{yr}$ extension), and the Cyprus Arc (predominantly convergence at $8.9 \pm 0.4 \mathrm{~mm} / \mathrm{yr}$ along the western segment, and $\sim 6.0 \pm 0.4 \mathrm{~mm} / \mathrm{yr}$ left lateral, strike slip along the eastern segment). These observations imply that the Sinai Peninsula and Levant region comprise a separate sub-plate sandwiched between the Arabian and Nubian plates.
\end{abstract}

(C) 2005 Elsevier B.V. All rights reserved.

Keywords: global positioning system; neotectonics; Sinai; plate tectonics; east Mediterranean

\footnotetext{
* Corresponding author. Tel.: +20 25560 046; fax: +20 255480 20.

E-mail addresses: salahm55@yahoo.com (S. Mahmoud), reilinge@erl.mit.edu (R. Reilinger).

${ }^{1}$ Tel.: +20 25560 046; fax: +20 25548020 .

${ }^{2}$ Tel.: +1 617253 7860; fax: +1 6172536385 .
}

\section{Introduction}

The Sinai Peninsula (Fig. 1) lies at the northern end of the Red Sea. Early plate tectonic models [1] identified the southern-most Sinai as lying near a rift-rifttransform triple junction (Red Sea, Gulf of Suez, Gulf of Aqaba/Dead Sea fault). Early seismotectonic studies of the Sinai area [2] considered the Sinai to be part of the African plate that is "splintering" off the main African plate as a result of the collision with 


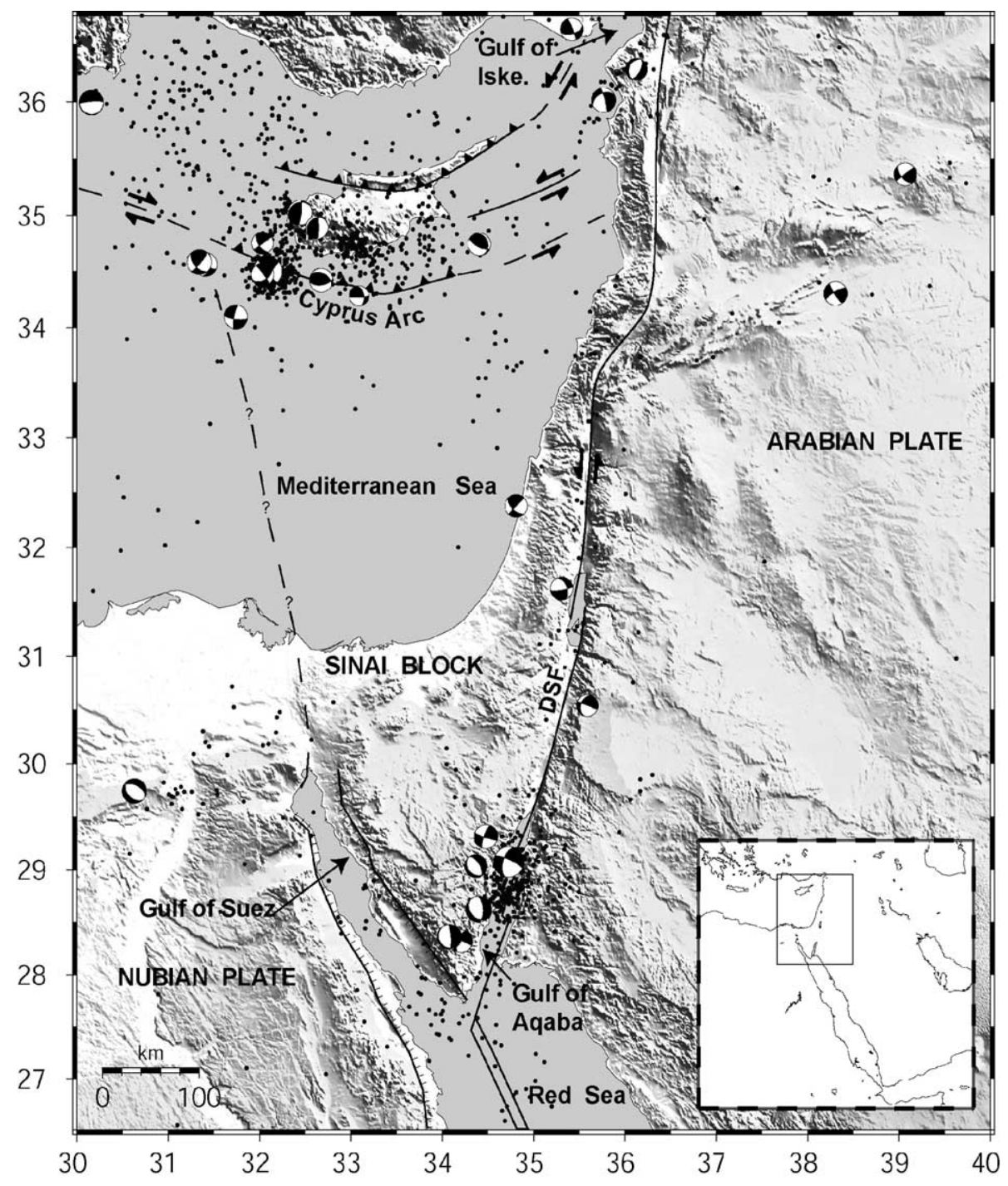

Fig. 1. Topographic (SRTM30) and tectonic map of the Sinai and surrounding region. Dots show seismicity (NEIC), focal mechanisms are from Harvard CMT. Inset shows location of study area within the context of the eastern Mediterranean. DSF=Dead Sea fault, Gulf of Iske. $=\mathrm{Gulf}$ of Iskenderum.

Eurasia. Recently, Salamon et al. [3] defined the Sinai tectonic block as a separate entity from Africa with the main Africa-Sinai boundary being extensional and lying within the Gulf of Suez. The Gulf of AqabaDead Sea fault (DSF) system forms the eastern boundary with Arabia. The northern and northwestern (i.e., north of the Gulf of Suez) boundaries of the Sinai Block are not well defined [4], but the northern boundary may correspond to the active collision/subduction boundary along the Cyprus Arc (Fig. 1).
The tectonic history of the Sinai region is intimately tied to the separation of the Arabian plate from Africa (Nubia) along the Red Sea rift system. Opening of the Red Sea was initiated in the early Oligocene [5,6]. The Red Sea rift basin was well established by early Miocene at which time rifting was concentrated along the Red Sea and its northern extension along the Gulf of Suez [7]. The Sinai Peninsula was formed in Middle to Late Miocene with the formation of the Gulf of Aqaba-DSF system. 
At this time, spreading in the Gulf of Suez slowed and the Red Sea-Gulf of Aqaba/DSF became the principal Nubian-Arabian boundary [8].

The southern and central Red Sea is characterized by active ocean spreading with rates varying from $\sim 15$ $\mathrm{mm} / \mathrm{yr}$ in the south to $\sim 6 \mathrm{~mm} / \mathrm{yr}$ in the northern rift $[9,10]$. At present, the rate of extension across the Gulf of Suez is thought to vary from zero in the north to $\sim 1 \mathrm{~mm} / \mathrm{yr}$ in the south [11]. The Gulf of AqabaDSF system is predominantly left-lateral strike slip with a small component of extension in the south (Gulf of Aqaba) and increasing compression towards the north. Estimates of current fault slip rates in the Gulf of Aqaba and along the DSF vary considerably (e.g., see [12] for references). Recent GPS observations in Israel (confined primarily to the west side of

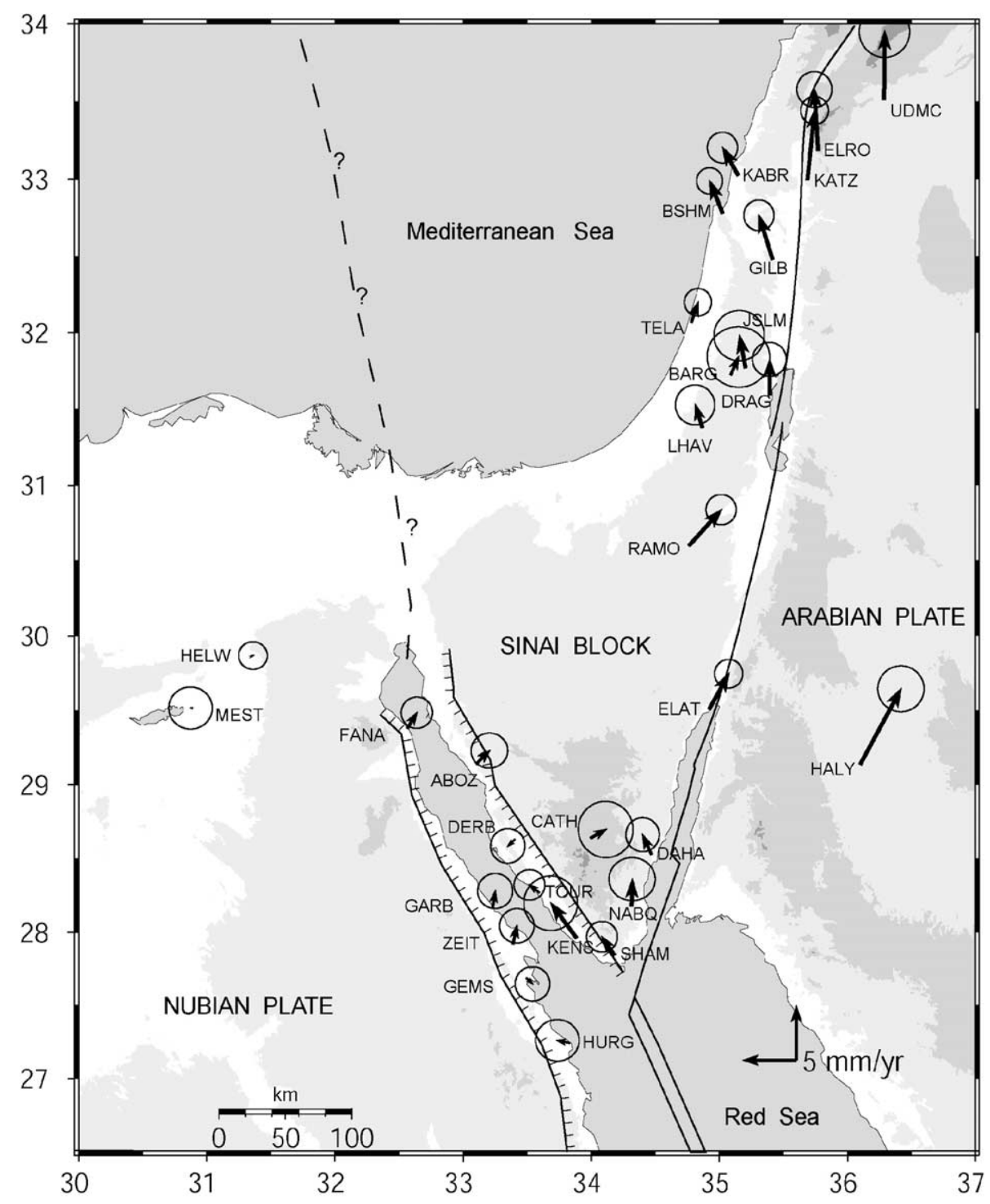

Fig. 2. Simplified tectonic map of the Sinai and surrounding regions showing GPS velocities and 95\% confidence ellipses relative to Nubia. Lines with tick-marks are normal faults, ticks on downthrown block, double line is Red Sea rift, plain lines are strike-slip faults. GPS velocities are given in Table 1 . 
the Dead Sea fault) have been interpreted to indicate left-lateral slip at $3.7 \pm 0.4 \mathrm{~mm} / \mathrm{yr}[12]$, while neotectonic studies suggest left-lateral slip at $4 \pm 2 \mathrm{~mm} / \mathrm{yr}$ since the Late Pleistocene [13]. These rates are lower than, but not significantly different (at 95\% confidence) from GPS estimates based on Arabia-Nubia overall motion, $5.8 \pm 1 \mathrm{~mm} / \mathrm{yr}$ that ignore possible Sinai Block motion ([10]; 95\% confidence errors are about $2.5 \times 1$-sigma uncertainty). As noted by McClusky et al. [10], northward motion of the Sinai would reduce geodetic estimates of slip rate on the DSF.

Because of its position within the zone of interaction of the African (Nubian), Arabian, and Eurasian (more properly, Anatolian) plates (Fig. 1), the tectonics of the Sinai region play a pivotal role in eastern Mediterranean kinematics. In addition, quantifying Sinai Block motion is necessary to constrain slip rates on the principal faults in the region, and consequently for evaluating earthquake hazards, particularly in the greater Cairo area and along the DSF.

In this paper we present GPS-derived velocities for a network of survey sites on the Sinai Peninsula and along the west side of the Gulf of Suez. We use these velocities, and the velocities of IGS-GPS stations in Israel [12] to constrain an elastic block model to test the consistency of the GPS velocities with coherent block motion and to estimate slip rates on blockbounding faults.

\section{GPS velocity field}

Fig. 2 shows GPS-derived velocities in the Sinai network along with velocities from continuously recording stations in surrounding areas relative to Nubia. Table 1 lists the velocity estimates and standard deviations. With the exception of sites CATH and KENS that were measured 4 times between 1997 and 2000 (sites destroyed), velocities for Sinai survey sites were determined from 5 to 7 surveys conducted between 1996 and 2003.

We analyze the GPS data using the GAMIT/ GLOBK software $[14,15]$ in a two-step approach [16]. In the first step, we use GPS phase observations from each day to estimate station coordinates, the zenith delay of the atmosphere at each station, and orbital and Earth orientation parameters (EOP). In the
Table 1

GPS velocities in an Africa (Nubia)-fixed reference frame and 1-sigma uncertainties for sites shown in Fig. 2

\begin{tabular}{|c|c|c|c|c|c|c|}
\hline Site & $\begin{array}{l}\text { Long. } \\
\left({ }^{\circ} \mathrm{E}\right)\end{array}$ & $\begin{array}{l}\text { Lat. } \\
\left({ }^{\circ} \mathrm{N}\right)\end{array}$ & $\begin{array}{l}\text { VE } \\
(\mathrm{mm} / \mathrm{yr})\end{array}$ & VN & $\mathrm{E} \pm$ & $\mathrm{N} \pm$ \\
\hline UDMC & 36.285 & 33.510 & $0.1(0.8)$ & $6.2(-0.3)$ & 1.0 & 1.0 \\
\hline SENK & 36.131 & 36.050 & $-2.7(1.0)$ & $4.5(0.5)$ & 0.7 & 0.6 \\
\hline HALY & 36.100 & 29.139 & $3.8(1.4)$ & $6.8(0.2)$ & 0.9 & 0.9 \\
\hline ELRO & 35.771 & 33.182 & $-0.3(0.2)$ & $5.6(0.4)$ & 0.7 & 0.7 \\
\hline KATZ & 35.688 & 32.995 & $0.7(1.0)$ & $6.3(1.5)$ & 0.5 & \\
\hline GILB & 35.416 & 32.479 & $-1.3(-0.9)$ & $4.0(0.8)$ & 0.6 & 0.6 \\
\hline DRAG & 35.392 & 31.593 & $0.0(-0.1)$ & $3.2(-0.2)$ & 0.7 & 0.7 \\
\hline JSLM & 35.302 & 31.771 & $-0.5(-0.4)$ & $2.9(0.2)$ & 1.0 & \\
\hline KABR & 35.145 & 33.023 & $-1.4(-0.9)$ & $2.5(0.0)$ & 0.6 & \\
\hline BARG & 35.089 & 31.723 & $0.7(1.0)$ & $1.6(-1.1)$ & 1.2 & \\
\hline BSHM & 35.023 & 32.779 & $-1.2(-0.7)$ & $2.9(0.5)$ & 0.5 & 0.5 \\
\hline ELAT & 34.921 & 29.509 & $1.8(0.8)$ & $3.2(-0.3)$ & 0.6 & \\
\hline LHAV & 34.866 & 31.378 & $-0.6(-0.5)$ & $2.0(-0$ & 0.8 & 0.8 \\
\hline TELA & 34.781 & 32.068 & $0.6(0.9)$ & $1.8(-0.5)$ & 0.5 & 0.5 \\
\hline RAMO & 34.763 & 30.598 & $2.8(2.8)$ & $3.0(0.5)$ & 0.6 & \\
\hline DAHA & 34.470 & 28.529 & $-0.8(-2.4)$ & $1.8(-1.3)$ & 0.7 & \\
\hline NABQ & 34.314 & 28.178 & $0.1(-0.7)$ & $2.4(0.2)$ & 0.9 & 0 . \\
\hline SHAM & 34.184 & 27.846 & $-1.2(-1.9)$ & $1.6(-0.3)$ & 0.6 & \\
\hline CATH & 33.995 & 28.639 & $1.4(1.1)$ & $0.8(-1.3)$ & 1.3 & \\
\hline KENS & 33.883 & 27.961 & $-2.3(-2.7)$ & $3.1(1.7)$ & 1.0 & 1. \\
\hline HURG & 33.832 & 27.244 & $-1.1(-1.8)$ & $0.2(-0.0)$ & 0.9 & 0.8 \\
\hline TOUR & 33.596 & 28.269 & $-0.9(-1.1)$ & $0.7(-0.6)$ & 0.6 & \\
\hline GEMS & 33.494 & 27.686 & $0.6(0.1)$ & $-0.5(-0.7)$ & 0.7 & 0 \\
\hline DERB & 33.404 & 28.631 & $-0.6(-0.7)$ & $-0.6(-2.1)$ & 0.7 & 0.7 \\
\hline $\mathrm{NICO}$ & 33.396 & 35.141 & $-3.7(1.5)$ & $-2.5(0.4)$ & 0.6 & 0.6 \\
\hline ZEIT & 33.391 & 27.919 & $0.3(-0.1)$ & 1.7 (1.3) & 0.7 & 0 . \\
\hline GARB & 33.228 & 28.163 & $0.3(-0.2)$ & $1.6(1.1)$ & 0.7 & \\
\hline $\mathrm{ABOZ}$ & 33.102 & 29.141 & $1.2(1.2)$ & $1.2(-0.4)$ & 0.7 & 0 . \\
\hline FANA & 32.566 & 29.379 & $0.9(0.7)$ & $1.4(1.0)$ & 0.6 & 0 . \\
\hline HELW & 31.344 & 29.862 & $0.2(0.1)$ & $0.1(0.3)$ & 0.6 & 0.6 \\
\hline
\end{tabular}

Numbers in brackets are residual velocities from the block model shown in Fig. 3.

second step we use the loosely constrained estimates of station coordinates, orbits, and EOP and their covariances from each day, aggregated by survey, as quasiobservations in a Kalman filter to estimate a consistent set of coordinates and velocities. We provide orbital control and tie the regional Sinai measurements to an external global reference frame by including in the regional analysis data from 3-5 continuously operating IGS stations for each day. The regional quasiobservations are then combined with quasi-observations from an analysis of phase data from over 100 stations performed by the Scripps Orbital and Permanent Array Center (SOPAC) at UC San Diego [17]. Before estimating velocities in the second step of our analysis, we examine the time series of position esti- 
mates to determine the appropriate weights to be applied to each group's surveys. For the velocity solution, we re-weight the quasi-observations such that the normalized long-term scatter in horizontal position for each group is equal to one. Finally, to account for correlated errors, we add to the assumed error in horizontal position a random walk component of 2 $\mathrm{mm} / \sqrt{ } \mathrm{yr}$ [18]. Uncertainties quoted in the text and tables are 1-sigma estimates while those shown in the figures are $95 \%$ confidence ellipses.

\section{Motion of the Sinai Block}

The GPS-velocity estimates shown in Fig. 2 and listed in Table 1 are given in a Nubia-fixed reference frame determined in this study by minimizing the velocities of GPS stations on the Nubian plate [10]. While velocity estimates for Sinai stations relative to their uncertainties are small, they indicate a generally consistent sense of motion towards the north at an average rate of $1.4 \pm 0.8 \mathrm{~mm} / \mathrm{yr}$, with a possible westerly component of $0.4 \pm 0.8 \mathrm{~mm} / \mathrm{yr}$. This same sense of motion, perhaps at a higher rate, characterizes IGS sites further north in Israel (Fig. 2, Table 1) as was also noted by Wdowinski et al. [12]. The average north rate for the five Israel IGS stations more than $45 \mathrm{~km}$ west of the main trace of the DSF (KABR, BSHM, TELA, LHAV, RAMO; see Fig. 2 and Table 1) is $2.4 \pm 0.6 \mathrm{~mm} / \mathrm{yr}$, with an insignificant westerly component of $0.04 \pm 0.6 \mathrm{~mm} / \mathrm{yr}$. This northerly rate is nominally higher, but not significantly different from the new GPS results in the southern Sinai Peninsula. The consistent GPS evidence for northward motion of the southern Sinai Peninsula from survey-mode GPS and the continuous IGS stations in Israel suggests that the Sinai Peninsula and the Levant west of the DSF in Israel move roughly coherently relative to Nubia. The variability of the Sinai survey results may reflect local disturbances associated with benchmark instability, hydrologic effects, local fault motions, or statistical fluctuations due to survey noise. The tendency for GPS sites on the west side of the Gulf of Suez to move roughly coherently with those on adjacent parts of the Peninsula indicates that present-day deformation associated with the western Sinai boundary includes the easternmost section of the Nubian crust west of the Gulf proper. This is consistent with the occurrence of large faults associated with the Gulf opening extending well west of the present boundaries of the Gulf itself [11], and with the distributed nature of seismic activity along the Gulf [3] (Fig. 1).

To test further the hypothesis of coherent motion of the Sinai Block, and to investigate the implications of the GPS data for slip rates on major faults, we have developed a block model following the procedure described by Meade et al. [19]. Prescribed parameters for the model include fault locations, and fault locking depths. The GPS data are used to constrain relative block motions. The model includes the effects of elastic strain accumulation on block bounding faults. Block motions are computed by minimizing in a least squares sense the residual GPS velocities (i.e., observed-modeled). For the model used here, all faults are vertical except for the western segment of the Cyprus Arc that has a $30^{\circ}$ dip to the NE. Fig. 3 shows our preferred model with the Sinai Block bounded by the Gulf of Aqaba/DSF system on the east, the Gulf of Suez on the west, and the Cyprus Arc to the north. North of the Gulf of Suez there is little evidence for active faulting [4], so the western Sinai boundary in Fig. 3 is not well established. For this model, we use a $13 \mathrm{~km}$ locking depth for the DSF (constrained by the model by minimizing the weighted root mean square [wrms] residual velocities, see inset, Fig. 3) and $15 \mathrm{~km}$ for other faults (unconstrained). Fig. 3 shows residual velocities in and around the Sinai Block for this model (listed in Table 1). Euler vectors for Sinai, Nubia, and Arabia relative to Eurasia resulting from this model are given in Table 2. The Nubia and Arabia Euler Vectors are in good agreement with those reported by McClusky et al. [10].

Fault slip rates on Sinai block-bounding faults are given in Fig. 3. These slip rates depend on the angle between the direction of relative motion between adjacent blocks and the local strike of the fault defining the block boundary at that location. The faultnormal rate varies as the sine of this angle and the fault parallel rate as the cosine. This is well illustrated by the variation in slip rates along the Dead Sea Fault at the Lebanon restraining bend (Fig. 3). Since the regional strikes of the better-defined faults are well constrained, the slip rates we report should be appropriate regional averages. On the other hand, local variations in fault strike will result in variations in fault-parallel and fault-normal slip rates that need to 


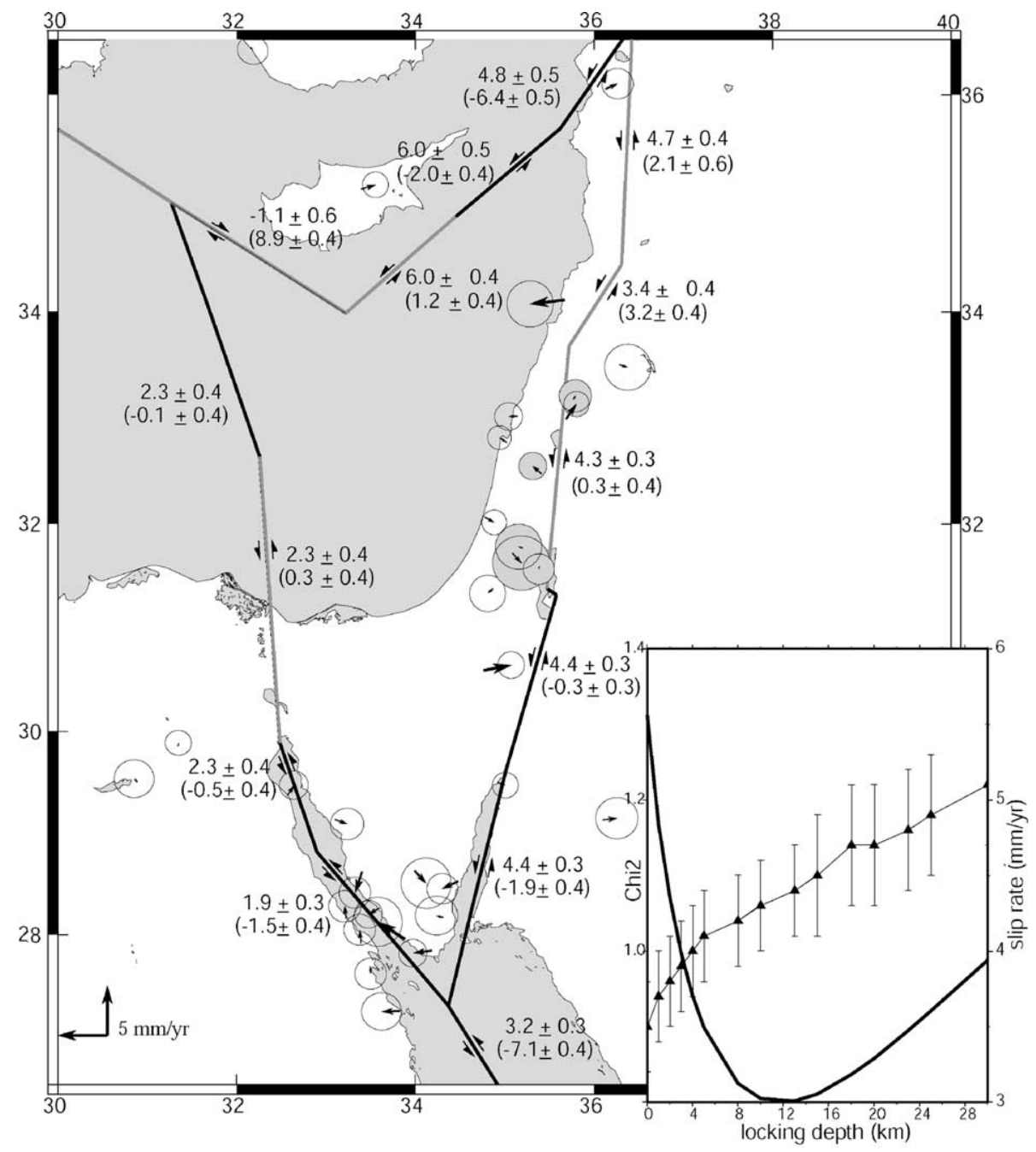

Fig. 3. Elastic block model for the Sinai area showing GPS residual velocities (given in Table 1) for the model described in the text. Faults are vertical and assigned locking depths of $15 \mathrm{~km}$ except for the Gulf of Aqaba/Dead Sea fault system that has a locking depth of $13 \mathrm{~km}$, and the western Cyprus Arc that has a $30^{\circ}$ dip down to the NE. Residuals are well within the uncertainties for the velocity determinations. Numbers show fault strike slip and fault-normal slip rates and 1-sigma formal uncertainties (fault normal component in brackets; negative for left lateral and extension). Slip rates are averages along each segment. Light modeled faults indicate segments with fault-normal shortening, and dark extension. Inset shows a plot of the local Chi*2 computed from sites close to the fault (shaded error ellipses indicate sites used to estimate fault locking depth) and estimated fault strike slip rate as a function of the locking depth for the Dead Sea fault. The best fit is for a $13 \mathrm{~km}$ locking depth and a strike slip rate of $4.3 \mathrm{~mm} / \mathrm{yr}$.

be considered when comparing geologic estimates with our model results.

Overall, the model results shown in Fig. 3 are consistent with the known tectonics of the area as deduced from geophysical and geological studies $[1,3,9]$. The northern Red Sea shows large extension $(-7.1 \pm 0.4 \mathrm{~mm} / \mathrm{yr})$ with a significant left-lateral strike slip component $(3.2 \pm 0.3 \mathrm{~mm} / \mathrm{yr})$. The Gulf of Aqaba shows small extension $(-1.9 \pm 0.4 \mathrm{~mm} / \mathrm{yr})$ and relatively large left-lateral strike slip $(4.4 \pm 0.3$ $\mathrm{mm} / \mathrm{yr}$ ). This grades into pure left-lateral strike slip (4.3-4.4 $\pm 0.3 \mathrm{~mm} / \mathrm{yr}$ ) along the DSF from the northern Gulf of Aqaba to the Lebanon restraining bend where strain is partitioned between left-lateral strike 
Table 2

Euler vectors relative to Eurasia and 1-sigma uncertainties estimated from this study

\begin{tabular}{llcc}
\hline Plate & $\begin{array}{l}\text { Long. } \\
\left({ }^{\circ} \mathrm{E}\right)\end{array}$ & $\begin{array}{l}\text { Lat. } \\
\left({ }^{\circ} \mathrm{N}\right)\end{array}$ & $\begin{array}{l}\text { W } \\
(\% / \mathrm{myr})\end{array}$ \\
\hline Sinai & $353 \pm 15$ & $11 \pm 10$ & $0.11 \pm 0.04$ \\
Nubia & $337 \pm 2$ & $-5 \pm 1$ & $0.058 \pm 0.002$ \\
Arabia & $19 \pm 1$ & $28 \pm 1$ & $0.44 \pm 0.01$ \\
\hline
\end{tabular}

For other Euler vector determinations for these plates, see compilations in Wdowinski et al. [12] and McClusky et al. [10].

slip $(3.4 \pm 0.4 \mathrm{~mm} / \mathrm{yr})$ and shortening $(3.2 \pm 0.4 \mathrm{~mm} /$ yr). North of the restraining bend, slip is partitioned between left-lateral strike slip $(4.7 \pm 0.4 \mathrm{~mm} / \mathrm{yr})$ and fault-normal shortening $(2.1 \pm 0.6 \mathrm{~mm} / \mathrm{yr})$. The western Cyprus Arc is undergoing shortening $(8.9 \pm 0.4$ $\mathrm{mm} / \mathrm{yr}$ on the $30^{\circ}$ dipping fault) and right-lateral strike slip $(-1.1 \pm 0.6)$, and the eastern Cyprus arc is characterized by left-lateral strike slip $(6.0 \pm 0.5 \mathrm{~mm} / \mathrm{yr})$ and fault-normal shortening $(1.2 \pm 0.4 \mathrm{~mm} / \mathrm{yr})$, with strike slip decreasing and extension increasing towards the Gulf of Iskenderum $(4.8 \pm 0.5 \mathrm{~mm} / \mathrm{yr}$ strike slip, $-6.4 \pm 0.5 \mathrm{~mm} / \mathrm{yr}$ extension). The Gulf of Suez is characterized by extension $(-1.5 \pm 0.4)$ and left lateral, strike slip $(1.9 \pm 0.3 \mathrm{~mm} / \mathrm{yr})$.

Although the GPS network around the Gulf of Suez includes sites near the Gulf and hence within the elastic strain field, the GPS data do not constrain the fault locking depth. This contrasts with the Dead Sea fault that has a well-defined locking depth of 13 $\mathrm{km}$ (inset, Fig. 3) that is consistent with the depth of earthquakes on the fault [3]. Large locking depths (up to $50 \mathrm{~km}$ ) are allowable by the model for the Gulf of Suez. We interpret this as indicating a broad zone of deformation around the Gulf of Suez, rather than a single fault accommodating Sinai Block motion. This is consistent with the distributed seismicity that characterizes the Gulf region [3].

While in general the GPS-constrained fault slip rates shown in Fig. 3 are consistent with regional tectonics, left lateral, strike slip faulting in the Gulf of Suez is unexpected. In support of this result, Bosworth and Strecker [20], using a variety of techniques to estimate the stress field around the Gulf of Suez, report a change in the orientation of the minimum horizontal stress during the Late Pleistocene from approximately normal to the Gulf $\left(\sim \mathrm{N} 55^{\circ} \mathrm{E}\right)$ to approximately $\mathrm{N}-\mathrm{S}$. Such a reorientation of the stress field is at least consistent with an increased component of left-lateral strike slip faulting. Furthermore, the possible increasing extension from north to south in the Gulf is consistent with geologic interpretations [8] as well as with the occurrence of compressional and extensional focal mechanisms [3].

Left-lateral slip on the DSF is smaller than rates determined from GPS-constrained models that do not include a separate Sinai Block. McClusky et al. [10] report left-lateral slip rates of $5.6 \pm 1 \mathrm{~mm} / \mathrm{yr}$ in the Gulf of Aqaba/Southern DSF to $6 \pm 1$ for the DSF in Syria compared to $4.4 \pm 0.3$ and $4.7 \pm 0.4 \mathrm{~mm} / \mathrm{yr}$ from this study. The reduced values for DSF slip rate are in better agreement with rates determined from near fault-GPS data in Israel (Wdowinski et al. [12] report $3.7 \pm 0.4$ from continuous GPS data mostly west of the fault trace [Fig. 2]) as well as geomorphologic rate estimates $(4 \pm 2 \mathrm{~mm} / \mathrm{yr}$ since the Late Pleistocene [13]).

\section{Conclusions}

Survey-mode GPS observations in and around the Sinai Peninsula, in combination with continuous GPS observations in Israel, provide evidence for coherent, northerly motion of the Sinai Block. On average, the survey data indicate northward motion of $1.4 \pm 0.8$ $\mathrm{mm} / \mathrm{yr}$. We use a simple elastic block model to characterize block motion and associated slip rates on block-bounding faults. These models suggest a 13 $\mathrm{km}$ locking depth for the DSF with left-lateral slip ranging from $4.4 \pm 0.3$ to $4.7 \pm 0.4 \mathrm{~mm} / \mathrm{yr}$ from the southern DSF to the DSF in western Syria. The Gulf of Suez is characterized by extension at $1.5 \pm 0.4 \mathrm{~mm} /$ $\mathrm{yr}$ and left-lateral strike slip motion at $1.9 \pm 0.3 \mathrm{~mm} /$ yr. This new block model provides a simple, kinematic description of the active tectonics of the easternmost Mediterranean, and implies that the Sinai Peninsula and Levant south of Lebanon forms a separate micro-plate between the Nubian and Arabian plates.

\section{Acknowledgements}

We thank Brendan Meade for providing us a copy of his block modeling software and assistance with its 
implementation. We are grateful to Muawia Barazangi, Francisco Gomez, Mustapha Meghraoui, and Shimon Wdowinski for helpful reviews that improved the paper. This research was supported in part by the NRIAG, a Lavoisier Grant from the French Ministry of Foreign Affairs (P.V.), and NSF grants EAR9909730, EAR-0305480, and INT-0001583 to MIT.

\section{References}

[1] D.P. McKenzie, Plate tectonics of the Mediterranean region, Nature 226 (1970) 239-243.

[2] A. Ben-Menahem, A. Nur, M. Vered, Tectonics, seismicity and structure of the Afro-Eurasian junction - the breaking of an incoherent plate, Phys. Earth Planet. Inter. 12 (1976) 1-50.

[3] A. Salamon, A. Hofstetter, Z. Garfunkel, H. Ron, Seismotectonics of the Sinai subplate - the eastern Mediterranean region, Geophys. J. Int. 155 (2003) 149-173

[4] J. Mascle, J. Benkhelil, G. Bellaiche, T. Zitter, J. Woodside, L. Loncke, Prismed II Scientific Party, Marine geologic evidence for a Levantine-Sinai plate, a new piece of the Mediterranean puzzle, Geology 28 (2000) 779-782.

[5] J. Dercourt, et al., Geological evolution of the Tethys belt from the Atlantic to the Pamirs since Lias, Tectonophysics 123 (1986) 241-315.

[6] M.S. Steckler, F. Berthelot, N. Lyberis, X. LePichon, Subsidence in the Gulf of Suez: implications for rifting and plate kinematics, Tectonophysics 153 (1988) 249-270.

[7] S. Joffe, Z. Garfunkel, Plate kinematics of the circum Red Sea-a re-evaluation, Tectonophysics 141 (1987) 5-22.

[8] M.S. Steckler, U.S. ten Brink, Lithospheric strength variations as a control on new plate boundaries: examples from the Arabian plate, Earth Planet. Sci. Lett. 79 (1986) 120-132.

[9] D. Chu, R.G. Gordon, Current plate motions across the Red Sea, Geophys. J. Int. 135 (1998) 313-328.

[10] S. McClusky, R. Reilinger, S. Mahmoud, D. Ben Sari, A. Tealeb, GPS constraints on Africa (Nubia) and Arabia plate motions, Geophys. J. Int. 155 (2003) 126-138.
[11] M.S. Steckler, S. Feinstein, B.P. Kohn, L. Lavier, M. Eyal, Pattern of mantle thinning from subsidence and heat flow measurements in the Gulf of Suez: evidence for the rotation of Suez and along-strike flow from the Red Sea, Tectonics 17 (1998) 903-920.

[12] S. Wdowinski, Y. Bock, G. Baer, L. Prawirodirdjo, N. Bechor, S. Naaman, R. Knafo, F. Forrai, Y. Melzer, GPS measurements of current crustal movements along the Dead Sea fault, J. Geophys. Res. 109 (2004) B05403, doi:10.1029/ 2003JB002640.

[13] Y. Klinger, J.P. Avouac, N. Abou Karaki, L. Dorbath, D. Bourles, J.L. Reyes, Slip rate on the Dead Sea transform fault in the northern Araba Valley (Jordan), Geophys. J. Int. 142 (2000) $755-768$.

[14] R.W. King, Y. Bock. Documentation of the MIT GPS Analysis Software: GAMIT, Massachusetts Institute of Technology, Cambridge, 2000.

[15] T.A. Herring, GLOBK: Global Kalman Filter VLBI and GPS Analysis Program version 4.1, Massachusetts Institute of Technology, Cambridge, MA, 1998.

[16] D. Dong, T.A. Herring, R.W. King, Estimating regional deformation from a combination of space and terrestrial geodetic data, J. Geod. 72 (1998) 200-211.

[17] Y. Bock, J. Behr, P. Fang, J. Dean, R. Leigh. Scripps Orbit and Permanent Array Center (SOPAC) and Southern California Permanent GPS Geodetic Array, in: EDITOR (Ed.), The Global Positioning System for the Geosciences, National Academy Press, Washington, DC, 1997, pp. 55-61

[18] S. McClusky, et al., GPS constraints on plate kinematics and dynamics in the eastern Mediterranean and Caucasus, J. Geophys. Res. 105 (2000) 5695-5719.

[19] B.J. Meade, B.H. Hager, S. McClusky, R.E. Reilinger, S. Ergintav, O. Lenk, A. Barka, H. Ozener, Estimates of seismic potential in the Marmara region from block models of secular deformation constrained by GPS measurements, Bull. Seismol. Soc. Am. 92 (2002) 208-215.

[20] W. Bosworth, M.R. Strecker, Stress field changes in the AfroArabian rift system during the Miocene to Recent period, Tectonophysics 278 (1997) 47-62. 